OPEN ACCESS

Edited by:

Tracylee Clarke,

California State University Channel

Islands, USA

Reviewed by:

Juliet Pinto,

Florida International University, USA Amanda D. Boyd,

Washington State University, USA

${ }^{*}$ Correspondence:

Andrea Marie Feldpausch-Parker amparker@esf.edu

Specialty section: This article was submitted to Science and Environmental Communication, a section of the journal

Frontiers in Communication

Received: 23 August 2016 Accepted: 13 December 2016 Published: 27 December 2016

Citation:

Rickard LN and FeldpauschParker AM (2016) Of Sea Lice and

Superfood: A Comparison of Regional and National News Media

Coverage of Aquaculture.

Front. Commun. 1:14

doi: 10.3389/fcomm.2016.00014

\section{Of Sea Lice and Superfood: A Comparison of Regional and National News Media Coverage of Aquaculture}

\author{
Laura N. Rickard ${ }^{1}$ and Andrea Marie Feldpausch-Parker ${ }^{2 *}$ \\ ${ }^{1}$ Communication and Journalism, University of Maine, Orono, ME, USA, ${ }^{2}$ Environmental Studies, State University of New \\ York College of Environmental Science and Forestry, Syracuse, NY, USA
}

As wild fisheries decline, aquaculture, or the cultivation of species in fresh and salt water, will provide the majority of seafood consumed worldwide. Given that aquaculture is an increasingly critical food "technology" - with implications for public opinion formation - we apply theory of social function systems and sustainability to a U.S. news media content analysis. We examine coverage of aquaculture ( $N=493$ articles) over a 10-year period (2005-2015), comparing four regional and four national newspapers for discussion of risks, benefits, science, economics, political/legal issues, and environmental sustainability. Results suggest the dominance of risk in regional and national news; however, we also find more recent attention to benefit and sustainability. Differences within and between regional and national newspaper coverage further suggest that the conversation about aquaculture varies within the U.S. is multidimensional and involves frequent co-occurrence of risk/benefit and social systems. Implications for future study are presented.

Keywords: aquaculture, content analysis, social systems theory, risk perception, sustainability

\section{INTRODUCTION}

As wild fisheries decline and world population grows, breeding, rearing, and harvesting species in salt- or fresh-water environments-known as aquaculture-will continue to provide the majority of the finfish and shellfish consumed globally [National Oceanic and Atmospheric Administration (NOAA), 2016]. Scientific and technological advances over the past three decades stand to make global aquaculture production increasingly environmentally sustainable and economically viable: a source of local employment and affordable protein [e.g., Ross et al. (2013)]. Yet, a legacy of environmental and human health concerns, and controversy surrounding siting operations and the use of genetically modified (GM) fish species suggest that perceived risks of aquaculture-for U.S. audiences, in particular-may loom large (Schlag, 2011; Kaptan et al., 2016). For example, just over a decade ago, a handful of highly publicized studies drew global attention to purportedly toxic levels of polychlorinated biphenyls (PCBs) in farmed Atlantic salmon, prompting debate in the news media and beyond about the interpretation of the scientific data, and the implications for human consumption (Hites et al., 2004; Senkowsky, 2004; Amberg and Hall, 2010). More recently, attention has focused on AquAdvantage, the first GM salmon to be raised in aquaculture operations-and, 
more critically, the first GM animal to be approved by the U.S. Food and Drug Administration (FDA) for human consumption (Waltz, 2016).

As has been the case with other products emerging from new "agri-food technologies" (Frewer et al., 2011), as GM salmon swims toward the supermarket shelves, consumer concern about product safety, as well as the potential for misinformation, may proliferate, posing implications for the future of the industry (Gurău and Ranchhod, 2016). To date, however, little is known about how Americans perceive aquaculture products, whether GM salmon or rope-grown mussels, or aquaculture practices, whether in land-based tanks or in offshore ocean pens, and how these perceptions might inform related behaviors, such as purchasing decisions or policy support (Chu et al., 2010; Hall and Amberg, 2013). In the absence of these data, a news media content analysis can provide a critical first step toward gauging the conditions for public opinion formation.

The present study takes this step, examining U.S. news media coverage of aquaculture over a 10-year period (2005-2015). Given aquaculture's status as an increasingly critical food "technology" in the U.S., we apply Luhmann's (1989) foundational theory of social function systems, as well as more recent application of this theory to the concept of environmental sustainability (Valentinov, 2014). Luhmann's social function systems are the broad-based systems within society that are used to respond to broad-based environmental issues such as climate change or pollution. These systems include, but are not limited to, those connected to sustainability such as science, economics, policy, and law. Through discussions within and between these systems, society is able to act upon an environmental issue or the development of a technology-such as the growing U.S. aquaculture industry and its implications for human and environmental health and safety. To account for differences in aquaculture development and practices across the country, we compare four regional news outlets and four national newspapers for discussion of aquaculture-related: risks and benefits; scientific, political/legal, and economic systems; and environmental sustainability. We examine both prominence and co-occurrence of these themes. Our results both confirm media analysis findings in other (e.g., European) contexts, and raise important questions for future research.

\section{Literature Review}

\section{Background: Aquaculture in the U.S.}

Presently, over $90 \%$ of the seafood Americans consume originates outsides of the U.S., and about half of those products-including finfish (e.g., salmon), shellfish (e.g., oysters), and other species (e.g., seaweed), are farmed in salt or fresh water [National Oceanic and Atmospheric Administration (NOAA), 2016]. Production methods vary considerably, from surface ocean pens, to landlocked ponds, to underwater ocean cages, as do inputs necessary to cultivate the species to harvest stage [National Oceanic and Atmospheric Administration (NOAA), 2016]. Advances in aquaculture science have led researchers to conclude that certain finfish species can be cultivated more efficiently than terrestrial species (e.g., chicken), with fewer related greenhouse gas emissions (Naylor et al., 2009; Torrissen et al., 2011). Moreover, some aquaculture production requires little to no input besides clean water (e.g., seaweed) and can contribute to ecological restoration in damaged habitats (e.g., oysters) (Naylor et al., 2009; Beck et al., 2011). Proponents also suggest that aquaculture can promote economic development internationally and domestically (Diana, 2009) and can be regulated under a sustainable certification system (Bush et al., 2013). More recently, food enthusiasts have increasingly sought out "boutique" aquaculture products, such as regional varieties of Eastern oysters (Crassostrea virginica) (Kandarian, 2015), or less commonly known seaweeds, like dulse (Palmaria palmata) (Pols, 2015), fueling the "local" food movement. Raised in ocean plots in the Northeast and Pacific Northwest, seaweed has gained recent acclaim in some food marketing circles as the next "superfood" - a designation that recognizes its nutritional qualities and potential to become a trendy additive in food products, from popcorn to pastries (Sneddon, 2015; Tarver, 2015).

Despite these benefits, aquaculture is not without its critics, and a lingering legacy of environmental and human health concern has sparked controversy in past decades. Intensive operations of ocean-penned salmon in the 1980s and 1990s (including in the U.S.) led to highly publicized environmental concerns of effluent runoff, debilitating fish disease, such as sea lice, and high levels of chemical pesticides (Diana, 2009; Schlag, 2010, 2011). Critics have also questioned the sustainability of using small fish to feed larger, carnivorous species, raised animal welfare concerns, and pointed to problems with raising GM species in open-ocean cages (Diana, 2009; Duarte et al., 2009). From a human health perspective, researchers have warned of negative health risks associated with consuming chemically contaminated farmed fish (Hites et al., 2004). In recent years, environmental and esthetic concerns have also generated public debate regarding aquaculture siting in the U.S. at local and federal levels (Eilperin, 2005), and contaminated seafood has drawn attention to inadequate environmental oversight in aquaculture operations abroad (Ahrens, 2007).

\section{Public Perception of Aquaculture}

Given these apparent benefits and drawbacks, what might U.S. consumers think of farmed seafood? To date, research on perceptions of aquaculture among American consumers is sparse (Chu et al., 2010; Hall and Amberg, 2013), with even less known about opinions toward emerging consumer products gaining mainstream popularity, such as seaweed (Chapman et al., 2015). Whereas growing terrestrial plants-such as grains, fruits, and vegetables - is familiar to most Americans, cultivating seafoodincluding finfish, shellfish, and seaweed-may be less so (Hall and Amberg, 2013). Even less widely known, perhaps, are the various benefits aquaculture can pose, including the promotion of food security and sustainable fisheries. Recent public opinion studies suggest that European consumers know little about the process of aquaculture, or the ubiquity of aquaculture products in the marketplace (Vanhonacker et al., 2011; Freeman et al., 2012; Schlag and Ystgaard, 2013). In the absence of information, many consumers infer environmental concerns associated with traditional terrestrial agriculture, including water pollution or excessive pesticide use (Whitmarsh and Palmieri, 2011; Freeman et al., 2012; Schlag and Ystgaard, 2013; Feucht and Zander, 2015), and trust in various government and scientific agencies 
to manage the risk becomes paramount (Luoma and Löfstedt, 2007; Frewer et al., 2011). Idealized as "natural," wild-caught fish tend to be perceived as superior in taste and quality to farmed fish, but also, in some cases, as prohibitively expensive (Hall and Amberg, 2013; Schlag and Ystgaard, 2013; Carlucci et al., 2015). Moreover, the increasing use of genetic modification in many forms of aquaculture, such as to create a faster-growing salmon or a triploid (sterile) oyster, can prompt the type of "dread" risk perceptions among public audiences-that is, elevated concern associated with perceived attributes of the hazard, such as lack of control or inequitable distribution of risks and benefits (Slovic, 1987) — associated with other GM foods [e.g., Frewer et al. (2002), Schlag (2011), Fabiansson and Fabiansson (2016), Kaptan et al. (2016)]. In some regions, stakeholders have challenged the siting of aquaculture operations for disrupting "lived experience," including access to coastal recreational areas, commercial fishing grounds, or the esthetic qualities of a place (e.g., scenic views) (D'Anna and Murray, 2015; Murray and D'Anna, 2015). At the same time, however, individuals may recognize the benefits posed by aquaculture, such as the provision of local jobs, or the creation of affordable protein (Mazur and Curtis, 2006; Schlag and Ystgaard, 2013; D’Anna and Murray, 2015).

As domestic aquaculture expands on U.S. land and in American waters, knowing what publics think-in order to design strategic risk communication, and foster support for public policy-will be increasingly critical to the industry and government sectors alike. While not a direct measure of public opinion, a news media content analysis is an important tool for understanding the climate for public opinion formation around a scientific issue, as we detail below.

\section{Media Coverage of Aquaculture}

When it comes to learning about scientific discoveries or issues of importance, public audiences tend to rely on mass media for information (Corbett and Durfee, 2004). As the "public discourse" surrounding a given issue (Hansen, 2010), news media coverage can contribute to the conditions for public opinion formation, making it a critical data source for understanding attention to scientific issues when direct measurement (such as a representative opinion survey) is unavailable (Schlag, 2011; Feldpausch-Parker et al., 2013), Importantly, whereas media content cannot be assumed to represent-in a direct sense-audience perceptions of an issue (i.e., "what to think"), agenda-setting theory suggests that such representations of an issue do instruct audiences about the relative importance of an issue in the public sphere (i.e., "what to think about") (Cohen, 1963; McCombs and Shaw, 1972; Scheufele, 1999). Specifically, agenda-setting theory posits “...a strong correlation between the emphasis that mass media place on certain issues... and the importance attributed to these issues by mass audiences" (Scheufele and Tewksbury, 2007 , p. 11). Exercising selective power in what they do and do not cover, mass media channels, such as newspapers, suggest to readers the significance of an issue, thus, making this issue accessible and directing subsequent attention. Further, the frames, or central, organizing ideas that journalists employ to describe a given issue, also contribute to making certain aspects of an issue more or less salient (Scheufele, 1999; Nisbet, 2014). Taken together, these agenda setting and framing effects matter, in that they can, indirectly, influence public opinion; an issue or event covered in great depth in the news media, for instance, becomes more accessible in an audience member's short-term memory and can direct further thinking and evaluation (Scheufele, 1999; Nisbet, 2014).

In the more specific case of media coverage of risk-related issues, seminal research in risk communication, such as the social amplification of risk framework (Kasperson et al., 1988; Kasperson and Kasperson, 1996), also suggests that news media serve as "amplification stations" - contributing to heightening or dampening concern about a given issue, as well as to secondary impacts, such as individual-level behavior (e.g., purchasing decisions) or societal-level policy (e.g., product labeling regulations). Research also suggests that the quantity of coverage may influence perception for risk, where more attention to a given issue in the news media resulting in an amplification of perceived risk (Mazur, 1981). Moreover, in the absence of firsthand experience, news media coverage can provide audiences with an indirect or "mediated reality": a foundation on which to form opinions and perceptions of a given risk or risk event (Binder et al., 2014). In the case of aquaculture in the U.S., this indirect experience is critical, given relatively limited direct involvement (e.g., employment) in the aquaculture sector, as compared to other countries (Valderrama et al., 2005).

With the exception of Amberg and Hall (2010), news media content analyses of aquaculture have focused predominantly on European newspapers, during the period between 2002 and 2007, and on salmon cultivation (Höijer et al., 2006; Schlag, 2010, 2011). Results of these studies suggest that aquaculture tends to be framed as a risk - to the environment, to human health, or bothand that benefits of aquaculture are often couched in economic terms (e.g., job creation). News media outlets have also covered scientific advances related to aquaculture, as Amberg and Hall (2010) illustrate in a content analysis of newspaper coverage of two highly publicized studies examining chemical contaminants in farmed salmon, focusing on the "contextual precision" (e.g., "dangerous levels" vs. "PCB levels of $30 \mathrm{ppb}$ ") used to present risks and benefits (see also Höijer et al., 2006). Moreover, these studies conclude that media coverage of aquaculture can reflect historical distinctions between sociopolitical settings and issues of social trust (Schlag, 2011). For instance, Höijer et al. (2006) describe how contextual factors, such as the "food scares" experienced in the UK in the early 2000s with the discovery of bovine spongiform encephalopathy in domestic cattle and widespread disapproval of GM food, has shaped British media coverage of aquaculture as another "new" - and, by extension, threatening-food technology [see also Nisbet and Newman (2015)].

By characterizing the advantages and drawbacks of certain forms of aquaculture as portrayed in news media accounts, the studies reviewed above lay the foundation for the present research. In particular, we build upon the "risk" and "benefit" frames to include the theoretical context of sustainability and systems thinking. Though the term "sustainability" is often mentioned in reference to aquaculture (e.g., Bush et al., 2013) —-whether positively or negatively-to date, no known studies have addressed the U.S. news media's coverage of the sustainability of aquaculture 
products or practices. This "sustainability frame," thus, could pose powerful implications, as the manner in which aquaculture is presented in the news may, at least indirectly, stand to impact support for and proliferation of U.S. aquaculture operations.

\section{Sustainability and Systems Thinking}

In this study, we draw upon Luhmann (1989) theory of social function systems as a means of exploring U.S. news media's portrayal of the sustainability of aquaculture from a social systems perspective. As a concept, sustainability arose from "sustainable development," a term popularized in the 1987 publication Our Common Future by the World Commission on Environment and Development, also referred to as the Brundtland Report (Peterson and Feldpausch, 2010). In this document, sustainable development was defined as "meeting the needs of the present without compromising the ability of future generations to meet their own needs" (World Commission on Environment and Development, 1987). Within the public realm, the concepts of sustainable development and sustainability are often discussed as an attempt to conserve the environment and its natural resources for future generations while still allowing for current economic development (Komiyama and Takeuchi, 2006; Peterson and Feldpausch, 2010). More specifically, "the term [sustainability] has been used to express the state in which levels of harvest in agriculture, fishery, and forestry are maintained within the capacity of the ecosystem, which is therefore recoverable" (Kajikawa, 2008, p. 218). Komiyama and Takeuchi (2006), however, point out that sustainable development is often linked to political agendas, which they deem problematic because of the biases it inserts into the relationship between science and economy. Moreover, with respect to the use of sustainability in the public lexicon, Peterson and Feldpausch (2010) (p. 857) argue that, "the definition's greatest strength, as well as its most damning weakness, is its ambiguity. This ambiguity not only has resulted in numerous arguments, but also reveals important power differentials and political relationships."

The ambiguity apparent in "sustainability" may also allow for its conceptualization within multiple social function systems (Luhmann, 1989), including economy, law, science, politics, religion, and education. As Luhmann (1989) describes, by providing a lens through which to view an issue, each social function system is unique-with its own individual operational structure (e.g., science functions with respect to the scientific method, whereas economics relies upon supply and demand structures). Though these systems are autonomous, they are also related. Therefore, communication between systems is possible-and even necessary-through so-called "resonance" (Luhmann, 1989): when an environmental event, such as a hurricane or an oil spill, triggers the social function systems such that the individual systems respond to the event, as well as to each other. Resonance is therefore critical for allowing society to address the complexities inherent in environmental issues and for creating the possibility of action; indeed, "whatever the economy does not bring about on its own has to be accomplished by politics with the help of its legal instrument"' (Luhmann, 1989, p. 63). As Feldpausch-Parker et al. (2013) demonstrate in a media analysis of the development of novel carbon capture and storage (CCS) technologies - a suite of climate change mitigation technologies used to capture anthropogenic $\mathrm{CO}_{2}$ and store it in terrestrial and geologic carbon sinks-these social function systems can be thought of as separate, yet inter-dependent-each reliant on the others to guide eventual action on an issue. For instance, the science system, which is responsible for research and development of CCS technologies, resonates with the political system, which is responsible for developing and implementing policies that would result in the adoption of such technologies. Finding mention of the economic and political/legal systems in the CCS articles to be tightly linked, the authors suggest that, "without an appropriate legal framework in place to address permitting, rights, and liability, many of the proposed projects cannot move forward, thus preventing the acquisition of jobs and other economic promises" (Feldpausch-Parker et al., 2013, p. 349).

Recognizing these linkages between sustainability and systems theory, Valentinov (2014) applied Luhmann (1989) to studying trade-offs between complexity and sustainability. According to Valentinov (2014), Luhmann's function systems attempt to reduce complexity through categorization, and that, as internal social system complexity grows, the presence of sustainability can become overshadowed. Luhmann's simplified function systems, therefore, allow society to bypass this obfuscation and acknowledge relationships with the biophysical environment. Following this line of inquiry, the present study investigates how U.S. news media coverage of aquaculture attends to the concept of sustainability, with respect to other social function systems.

\section{Research Questions (RQs)}

Given recent discussion of the connections between sustainability and systems complexity (Valentinov, 2014), as well as aquaculture's distinction as an emerging food "technology" in the U.S., the present study analyzes news media coverage using Luhmann's (1989) social function systems of science, economy, and politics/ law. Similar to other media analyses applying Luhmann (1989), we consider the politics and legal function systems jointly because of their closely tied presentation in media coverage, and negative impact on intercoder reliability when separated (FeldpauschParker et al., 2013, 2015). Furthermore, we incorporate the risk/ benefit framing applied in previous media studies of aquaculture (e.g., Schlag, 2010, 2011) to explore how sustainability and its related function systems frame discussion of aquaculture. Finally, by comparing four high-circulation publications at the U.S. statelevel with four "elite" news publications over a 10-year period (2005-2015), we can better understand whether differences in the type or relative development of the local aquaculture industry seem to matter in the news media framing of the issue (Höijer et al., 2006; Batill and Feldpausch-Parker, 2013). Thus, we pose the following RQs:

RQ1: To what extent do U.S. newspapers discuss aquaculture in terms of risk, benefit, economics, politics/law, science, and sustainability? Over the past decade, does coverage vary from year-to-year (RQ1a)?

RQ2: Are there differences between national and regional newspaper coverage in discussing aquaculture in terms of risk, benefit, economics, politics/law, science, and 
sustainability? Are there differences in coverage withinnational newspapers (RQ2a) and/or within-regional newspapers (RQ2b)?

RQ3: Are there differences in the extent to which these themes (i.e., risk, benefit, economics politics/law, science, and sustainability) co-occur within a given article? Are there differences within-national newspapers (RQ3a) and/or within-regional newspapers (RQ3b)?

\section{MATERIALS AND METHODS}

\section{Pilot Test}

Prior to beginning the present study, three members of the research team coded 35 articles in which aquaculture was discussed in several regional U.S. news publications (e.g., The Providence Journal, Bangor Daily News), none of which appeared in the final dataset. The research team talked through disagreements, modifying the codebook as necessary. After reliability was judged acceptable on each variable (see below), as measured by Cohen's kappa of 0.70 or above, the team proceeded to the study sample.

\section{Sample Selection}

The present study investigated regional and national news media coverage of aquaculture by selecting publications representative of four states-Louisiana, Maine, Massachusetts, and California-differing in the type and extent of aquaculture practiced, as assessed by the 2013 U.S. Census of Aquaculture. These states also vary in population, rural/urban character, and region of the U.S. (Table 1). To reflect these distinctions, the study sampled the largest circulation daily newspaper from each state-The Advocate (Louisiana), The Portland Press Herald (Maine), The Boston Globe (Massachusetts), and The Los Angeles Times (California) - in addition to four national newspapers: The New York Times, The Washington Post, The Wall Street Journal, and USA Today. Often considered "agenda-setting" (Boykoff and Boykoff, 2004), these four publications were included to explore the possible role of the national-level press in influencing both these and other state-level publications not included in the sample.

Using the search terms "aquaculture OR sea farming OR fish farming," we gathered articles appearing in the selected publications between January 1,2005 and December 31, 2015 from the databases LexisNexis Academic and Proquest Newsstand; given the eight newspapers included in the study, both databases were needed to account for different publication availability in each individual database. Moreover, due to limited availability in Proquest Newsstand of full-text versions of The Advocate articles appearing during in the study period, articles were also accessed using the search function for the newspaper's digital archive, available through paid subscription. Articles removed from the final sample included those that: (1) mentioned aquaculture only in relation to another, central story (e.g., the receipt of grant funding); (2) mentioned aquaculture with respect to food (or cooking) without commenting on the process of aquaculture; (3) described community events (e.g., a shellfish farm lease hearing) without commenting on the process of aquaculture; and (4) were book reviews, obituaries, blog posts, or magazine articles associated with the publication. Provided they did not violate the above criteria, articles were retained irrespective of length and could include any type of article, including editorials or commentaries.

\section{Variables}

We coded articles based on presence of a given variable, regardless of how many times this variable was mentioned within a news article.

\section{Risk}

"Risk" focused on past, present, or future environmental problems associated with aquaculture, such as impacts of aquaculture on wild fisheries, pollution related to aquaculture, or invasive species. Also included were health risks to humans posed by food safety (e.g., vibrio in shellfish), and environmental or health-related risks to the successful implementation of aquaculture (e.g., drought). Finally, this variable also included environmental or health-related risks to the successful implementation of aquaculture (e.g., weather conditions).

\section{Benefit}

"Benefit" identified past, present, or future environmental benefits associated with aquaculture, such as the ability of shellfish to improve water quality, or human health benefits, such as those related to consuming seafood.

TABLE 1 | Comparison between U.S. states included in study.

\begin{tabular}{|c|c|c|c|c|}
\hline & California & Louisiana & Maine & Massachusetts \\
\hline Popular aquaculture products & $\begin{array}{c}\text { Finfish (e.g., trout), } \\
\text { shellfish (e.g., oysters) }\end{array}$ & $\begin{array}{c}\text { Finfish (e.g., catfish), } \\
\text { shellfish (e.g., crawfish) }\end{array}$ & $\begin{array}{c}\text { Shellfish (e.g., oysters, mussels), } \\
\text { finfish (e.g., salmon), seaweed } \\
\text { (e.g., kelp) }\end{array}$ & Shellfish (e.g., oysters) \\
\hline Number of aquaculture farms ${ }^{a}$ & 124 & 500 & 35 & 145 \\
\hline Sales of aquaculture products $(\$ 1,000)^{\mathrm{a}}$ & $\$ 83,583$ & $\$ 90,639$ & $\$ 57,326$ & $\$ 18,065$ \\
\hline Daily newspaper (circulation) & $\begin{array}{c}\text { Los Angeles Times } \\
(600,449)\end{array}$ & $\begin{array}{c}\text { The Advocate } \\
(98,000)\end{array}$ & $\begin{array}{c}\text { Portland Press Herald } \\
(47,326)\end{array}$ & $\begin{array}{c}\text { Boston Globe } \\
(245,572)\end{array}$ \\
\hline State population (\% rural) ${ }^{\mathrm{b}}$ & $\begin{array}{c}38,802,500 \\
(5.05)\end{array}$ & $\begin{array}{c}4,649,676 \\
(26.81)\end{array}$ & $\begin{array}{c}1,330,089 \\
(61.34)\end{array}$ & $\begin{array}{l}6,745,408 \\
(8.03)\end{array}$ \\
\hline
\end{tabular}

aU.S. Census of Aquaculture, 2013.

bU.S. Census, 2014 and 2010. 


\section{Science}

"Science" referred to scientific developments, research, technology, and scientific facilities related to aquaculture, such as those used to develop seed stock for oyster aquaculture operations.

\section{Political/Legal}

"Political/legal" focused on political discussion surrounding aquaculture and also included conflict or controversy between opposing groups and/or reference to laws, bills, lawsuits, permitting issues, or policy/policy proposals related to aquaculture.

\section{Sustainability}

"Sustainability" indicated that the article mentioned the word "sustainability," "sustainable," "sustain," or "sustainable development" as it related to the Brundtland Report's 1987 definition. The article needed to mention the sustainability of aquaculture in environmental, rather than other terms (e.g., economic) to ensure that sustainability was not being used in its more generic form.

In addition to these variables, coders also recorded any geographic location mentioned in the article (i.e., North America, Europe, Central/South America, Asia, or other location), and the type of aquaculture mentioned (i.e., finfish, shellfish, seaweed, or other).

\section{Coding Process and Reliability Testing}

We divided the task of coding between three coders. To test for reliability, the first author selected approximately $10 \%$ of the articles $(n=53)$ in the full data set at random (Riffe et al., 2014). Three coders next coded each article; resulting Cohen's kappa values were judged acceptable for each variable used in this study (risk $=0.77$, benefit $=0.67$, economics $=0.69$, sustainability $=0.77$, science $=0.83$, and political $/$ legal $=0.82$ ). In the case of disagreements, we used the "majority decision" rule to reach a final code to be included in the data set. Data were analyzed using SPSS (version 23).

\section{RESULTS}

The final dataset included $N=493$ articles from The Boston Globe $(n=87)$, Portland Press Herald $(n=81)$, The Los Angeles Times $(n=52)$, The Advocate $(n=42)$, The New York Times $(n=104)$, The Washington Post $(n=80)$, USA Today $(n=14)$, and The Wall Street Journal $(n=33)$.

\section{Trends in Aquaculture Coverage (RQ1) Year-by-Year}

The first RQ asked how U.S. newspapers (four regional and four national publications, $N=493$ articles) discuss aquaculture in terms of risk, benefits, economics, political/legal issues, science, and sustainability. Over the 10 -year study period, coverage of aquaculture in the newspapers sampled varied, with a low of 31 articles in 2009, and a peak of 64 articles in 2007 (Figure 1). Since 2013, coverage of aquaculture, in general, has been increasing, with attention to seaweed and shellfish aquaculture particularly on the rise. Except for the first year sampled (2005), economics appeared in more articles in the overall sample than any other theme. While risk has been a prominent theme of aquaculture news coverage in the sample over the past decade, particular spikes in risk coverage in 2007 and 2010 suggest the possible

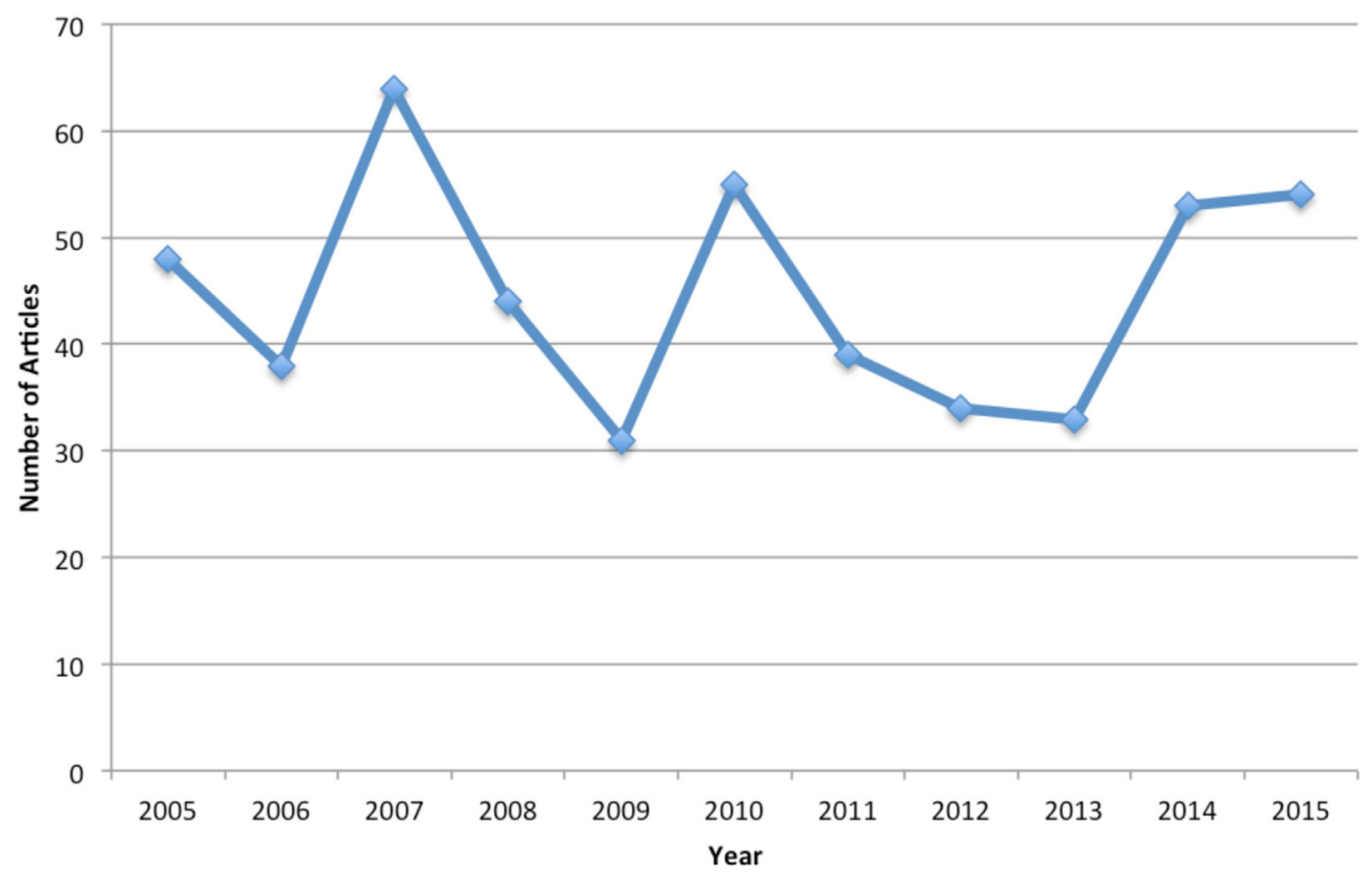

FIGURE 1 | Coverage of aquaculture, combined sample ( $N=493), 2005-2015$ 
occurrence of relevant events, possibly political in nature, given the close tracking of political/legal coverage (Figure 2). Coverage of aquaculture benefits remained somewhat flat until 2013, when, along with sustainability, mention began to increase.

\section{Ten Years}

Finfish aquaculture was discussed in the majority of all articles $(62.3 \% ; n=307)$, with shellfish $(51.5 \% ; n=254)$ and seaweed aquaculture less prevalent $(5.3 \% ; n=26)$. Almost all articles discussed aquaculture in the context of North America (94.1\%; $n=464)$, though Europe $(18.7 \% ; n=92)$, Asia $(29.8 \% ; n=147)$, and Central/South America $(14 \% ; n=69)$ also received mention. The large majority of articles covered economic issues related to aquaculture $(74.2 \% ; n=366)$. About half $(51.9 \%$; $n=256$ ) discussed environmental or human health-related risks and political/legal issues $(50.1 \% ; n=247)$. Just over one-third $(37.1 \% ; n=183)$ discussed aquaculture in terms of science or scientific developments. Fewer articles overall touched on the environmental or human health benefits of aquaculture, amounting to $31.4 \%$ of the sample $(n=155)$. A similar number of articles $(31.2 \%$; $n=154)$ described aquaculture in terms of sustainability.

\section{Differences in Regional and National Coverage (RQ2) \\ Regional vs. National}

The second RQ compared differences in aquaculture coverage within and between a set of national (The New York Times, The Washington Post, The Wall Street Journal, USA Today) and regional (The Boston Globe, Portland Press Herald, The Advocate, The Los
Angeles Times) newspapers over the 10-year study period. Results suggest an association between coverage of risk and news outlet (i.e., regional vs. national) $\left[\chi^{2}(1)=20.47, p<0.001\right]$. While $42.4 \%$ of regional newspaper articles described the risks associated with aquaculture, $62.8 \%$ of national newspaper articles did the same. Coverage of the benefits of aquaculture was also associated with news outlet $\left[\chi^{2}(1)=7.81, p<0.01\right]$. Compared to $37.7 \%$ of national newspaper articles, only $26 \%$ of regional newspaper articles mentioned aquaculture benefits. We also found a significant association between sustainability and news outlet $\left[\chi^{2}(1)=7.27\right.$, $p<0.01$ ], with $37.2 \%$ of all national newspaper articles describing aquaculture in terms of sustainability, as opposed to $26 \%$ of regional newspaper articles. Neither political/legal aspects of aquaculture $\left[\chi^{2}(1)=1.72, p>0.05\right]$, economics $\left[\chi^{2}(1)=0.095\right.$, $p>0.05]$, nor science $\left[\chi^{2}(1)=0.96, p>0.05\right]$ was associated with regional vs. national news outlet (Figure 3 ).

\section{Within-Regional Differences}

Within the set of regional newspapers, we found an association between coverage of risk and newspaper $\left[\chi^{2}(3)=42.53, p<0.001\right]$. Whereas $64.3 \%$ of all Advocate articles mentioned risk, only $13.6 \%$ of Portland Press Herald articles did the same. Coverage of benefit also varied among regional newspapers $\left[\chi^{2}(3)=23.18\right.$, $p<0.001$ ], with $39.1 \%$ of all Boston Globe articles mentioning the benefits of aquaculture, as compared to just $9.5 \%$ of all Advocate articles. Results suggested a similar story for sustainability, with one-third (33.3\%) of all Boston Globe articles mentioning "sustainable" aquaculture, compared to just $7.1 \%$ of all Advocate articles $\left[\chi^{2}(3)=11.69, p<0.01\right]$. Neither covering the political/ legal aspects of aquaculture $\left[\chi^{2}(3)=3.44, p>0.05\right]$, economics $\left[\chi^{2}(3)=4.34, p>0.05\right]$, nor science was associated with regional news outlet $\left[\chi^{2}(3)=0.45, p>0.05\right]$ (Figure 4).

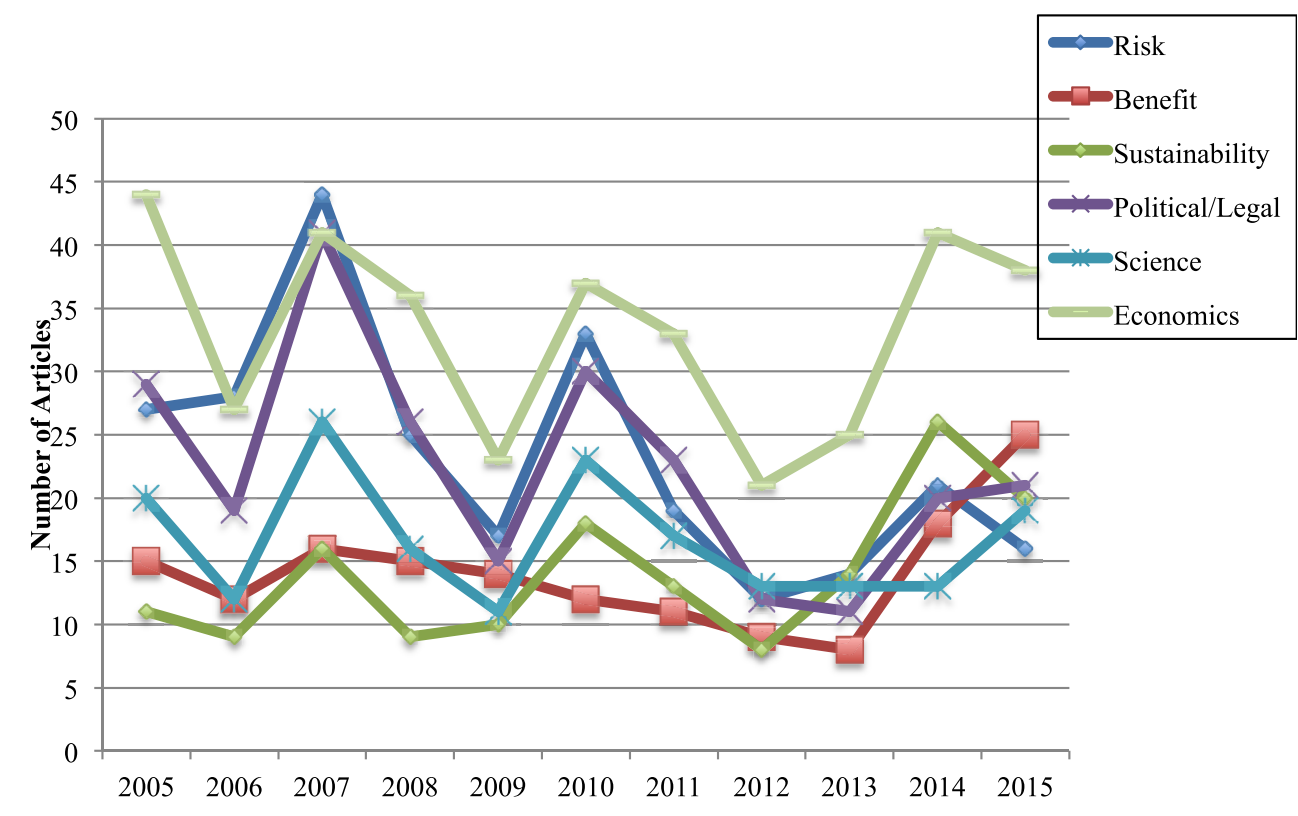

FIGURE 2 | Coverage of aquaculture by frame and year, combined sample $(N=493), 2005-2015$. 


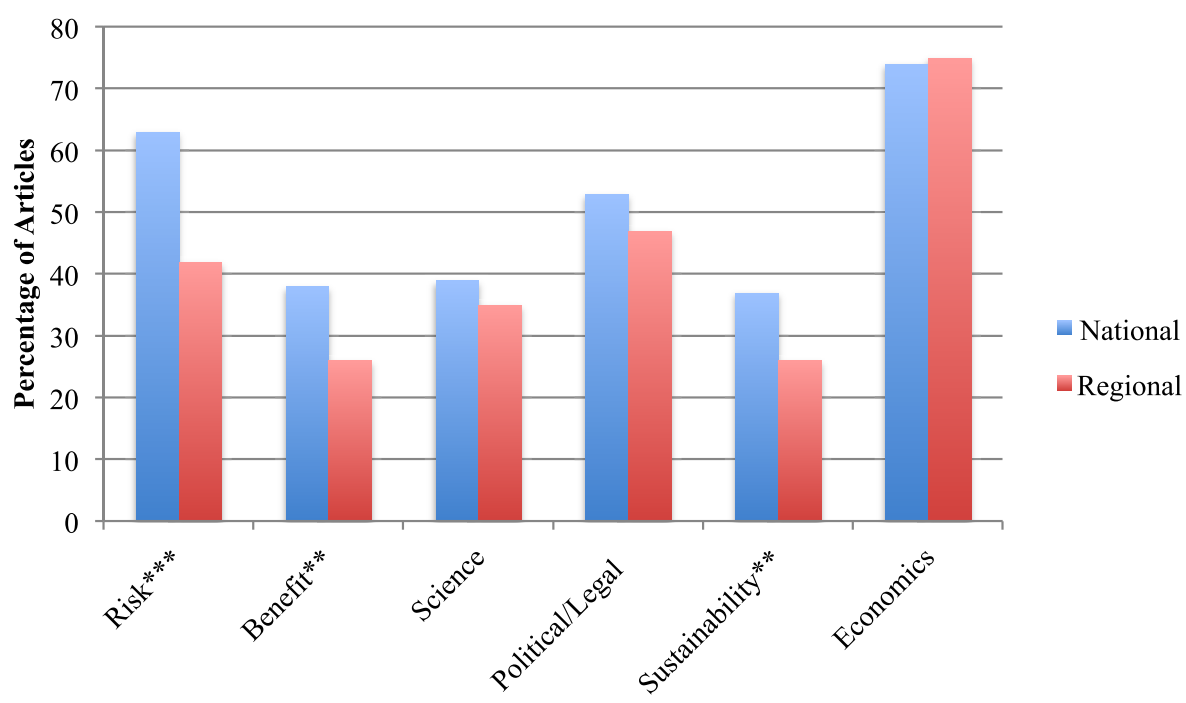

FIGURE 3 | Coverage of aquaculture by frame, combined sample $(\mathbf{N}=\mathbf{4 9 3})$. Note: ${ }^{\star \star \star} p<0.001,{ }^{\star \star} p<0.01,{ }^{\star} p<0.05$.

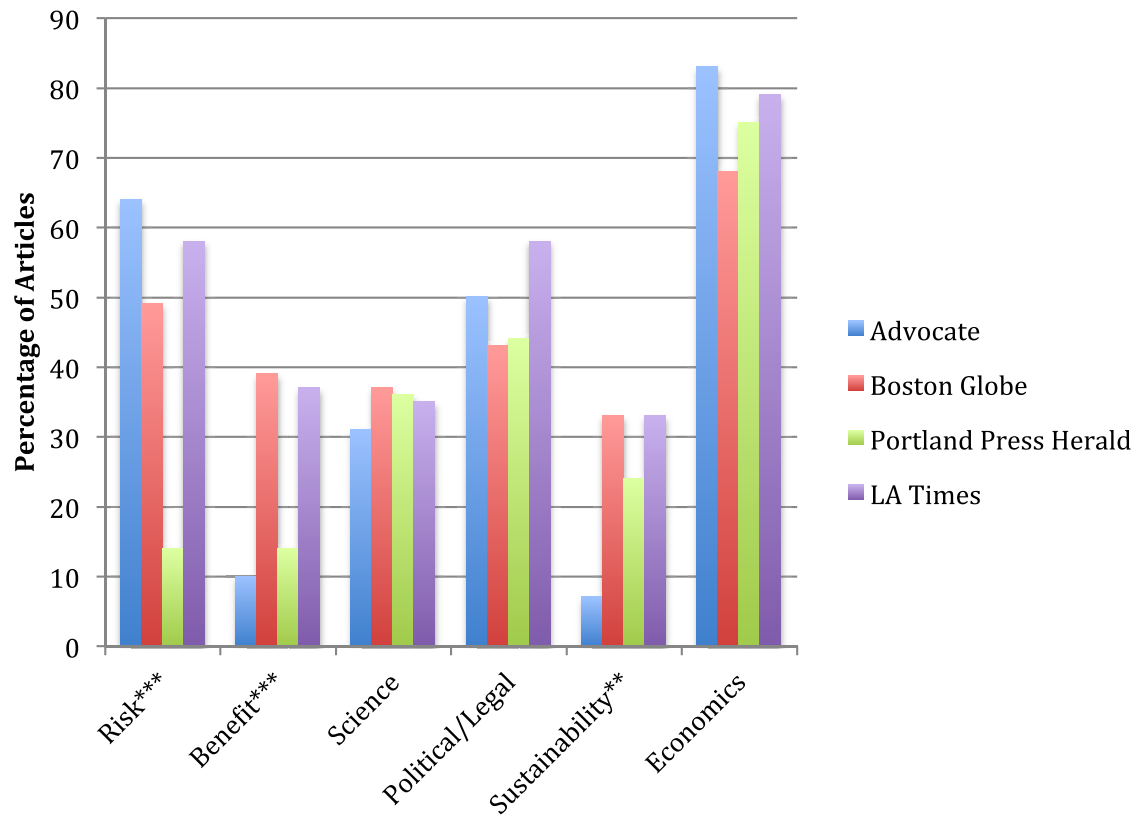

FIGURE 4 | Coverage of aquaculture by frame, regional sample $(\boldsymbol{n}=\mathbf{2 6 2})$. Note: ${ }^{\star \star \star} p<0.001,{ }^{\star \star} p<0.01,{ }^{\star} p<0.05$.

\section{Within-National Differences}

Coverage of risk was marginally associated with national news outlet $\left[\chi^{2}(3)=7.57, p=0.056\right]$, with $71.4 \%$ of USA Today articles and $71.2 \%$ of New York Times articles covering risk, as compared to just over half of all Washington Post articles (52.5\%) and Wall Street Journal articles (57.6\%). Neither coverage of science $\left[\chi^{2}(3)=4.88, p>0.05\right]$, benefit $\left[\chi^{2}(3)=6.47, p>0.05\right]$, economics $\left[\chi^{2}(3)=0.312, p>0.05\right]$, nor sustainability $\left[\chi^{2}(3)=2.12, p>0.05\right]$ was associated with national news outlet; however, unlike within the full sample and regional samples, within the national sample, there was an association between coverage of political/legal aspects of aquaculture and newspaper $\left[\chi^{2}(3)=8.19, p<0.05\right]$, with $62.5 \%$ of all New York Times articles covering politics, as opposed to just $35.7 \%$ of USA Today articles (Figure 5).

\section{Co-occurrence of Coverage (RQ3)}

The third RQ examined the extent to which the themes cooccurred within: (1) the full sample; (2) the national sample; and 


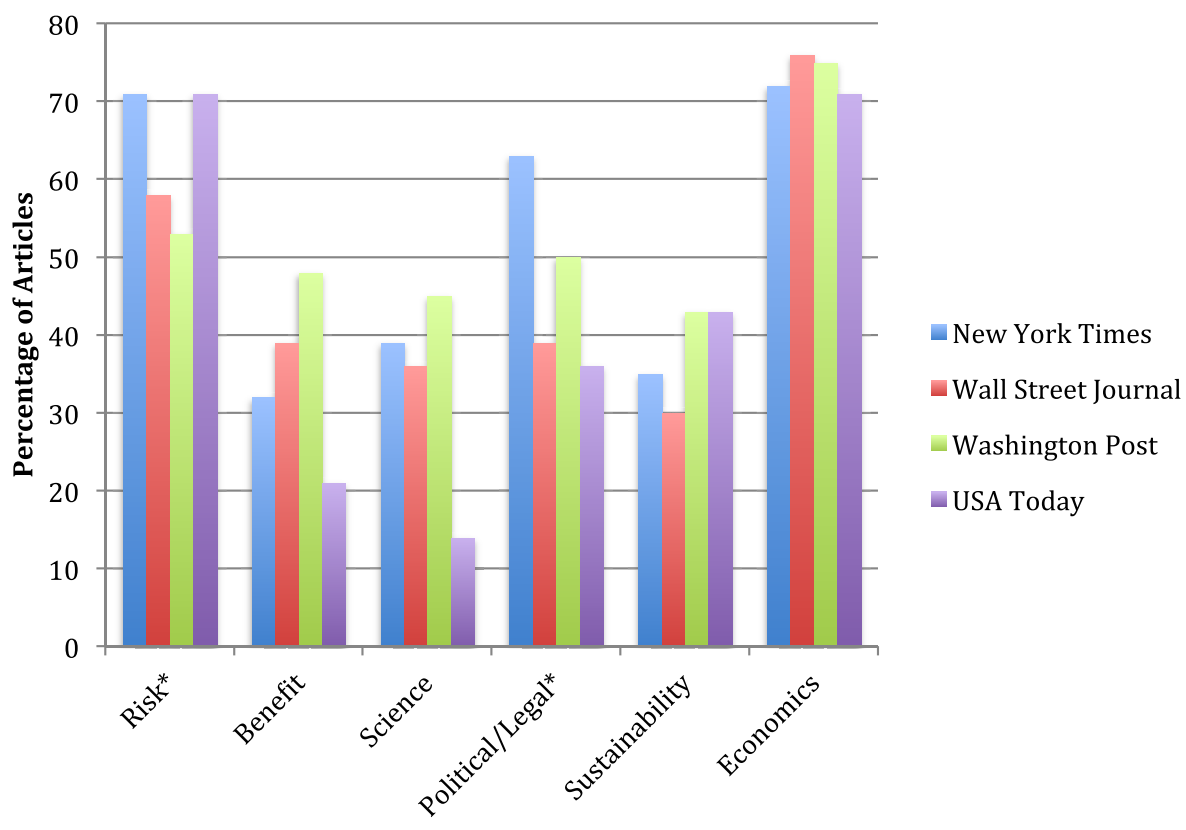

FIGURE 5 | Coverage of aquaculture by frame, national sample $(\boldsymbol{n}=\mathbf{2 3 1})$. Note: ${ }^{\star \star \star} p<0.001,{ }^{\star \star} p<0.01,{ }^{\star} p<0.05$.

(3) the regional sample (Table 2). Within the full sample, risk and political/legal discussion co-occurred $\left[\chi^{2}(1)=21.54, p<0.001\right]$, with $31.2 \%$ of all articles mentioning both risk and political/legal aspects of aquaculture. Mention of risk also co-occurred with mention of sustainability in $18.5 \%$ of all articles $\left[\chi^{2}(1)=4.60\right.$, $p<0.05]$ and with science in $24.7 \%$ of all articles $\left[\chi^{2}(1)=25.33\right.$, $p<0.001]$. Just $14.6 \%$ of all articles referred to both benefits and sustainability of aquaculture $\left[\chi^{2}(1)=24.36, p<0.001\right]$, and $13.8 \%$ mentioned both political/legal and sustainability $\left[\chi^{2}(1)=3.17\right.$, $p<0.05]$. Political/legal and scientific issues were discussed in $20.9 \%$ of all articles $\left[\chi^{2}(1)=4.45, p<0.05\right]$.

Within the national and the regional data sets, the statistical significance of these associations differed, as did their prominence within the sample. National newspaper articles contained the same significant co-occurrences as the full dataset, with the exception of the associations between political/legal and science and political/ legal and sustainability. Additionally, we observed a significant association between mention of economics and risk $\left[\chi^{2}(1)=4.29\right.$, $p<0.05$ ], with $43.3 \%$ of all national newspaper articles discussing both themes. Within the regional newspapers, we observed four of the same thematic associations as in the national and full datasets (i.e., risk and political/legal, risk and science, benefit and sustainability, political/legal, and sustainability), and two additional significant co-occurrences: risk and benefit $\left[\chi^{2}(1)=4.21, p<0.05\right.$; $13.7 \%$ of all regional sample articles] and benefit and science $\left[\chi^{2}(1)=4.42, p<0.05 ; 11.8 \%\right.$ of all regional sample articles $]$.

\section{DISCUSSION}

An emerging technology with environmental, political, economic, and human health implications-about which many
TABLE 2 | Co-occurrence of themes by sample.

\begin{tabular}{|c|c|c|c|}
\hline & $\begin{array}{c}\text { Full sample } \\
(N=493)\end{array}$ & $\begin{array}{l}\text { National sample } \\
\quad(n=231)\end{array}$ & $\begin{array}{l}\text { Regional sample } \\
\qquad(n=262)\end{array}$ \\
\hline $\mathrm{R}+\mathrm{Pa}^{\mathrm{a}}$ & $31.2 \% \%^{\star \star \star}$ & $37.7 \%$ ** & 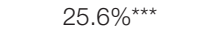 \\
\hline$R+$ Sus & $18.5 \%$ * & $27.7 \%$ ** & $\mathrm{ns}$ \\
\hline $\mathrm{R}+\mathrm{Sci}$ & $24.7 \%^{\star \star \star}$ & $31.2 \% \%^{\star \star \star}$ & $19.1 \%$ ** \\
\hline B + Sus & 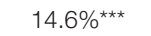 & 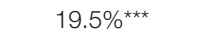 & $10.3 \%$ ** \\
\hline $\mathrm{P}+$ Sci & $20.9 \%$ * & $\mathrm{ns}$ & ns \\
\hline$P+$ Sus & $13.8 \%$ * & ns & $9.9 \% *$ \\
\hline$R+B$ & ns & ns & $13.7 \%$ * \\
\hline $\mathrm{B}+\mathrm{Sci}$ & ns & ns & $11.8 \%$ * \\
\hline$E+R$ & ns & $43.3 \%$ * & ns \\
\hline
\end{tabular}

${ }^{a} R$, risk; P, political/legal; Sus, sustainability; $B$, benefit; Sci, science; $E$, economics. Chi-square statistic significant at ${ }^{* * *} p<0.001,{ }^{* *} p<0.01,{ }^{*} p<0.05$. Percentages refer to percentage of articles in each sample that mention both themes. Categories in which results are non-significant for all three samples are not shown.

Americans know little-aquaculture is poised to be a topic of increasing public interest, and possibly concern (Schlag, 2010). Results from this study suggest that, over the past decade, risk has dominated the aquaculture discussion in both the regional and national newspapers sampled; more recent attention to benefit and sustainability may be explained, in part, to the growing shellfish aquaculture industry and popularity of the "local" food movement in the Northeast. Differences within and between regional and national newspaper coverage further suggest that the conversation about aquaculture may vary geographically within the U.S. and is multidimensional with co-occurrence of risk/benefit and social systems (e.g., risk and political/legal) in a single article. Before discussing these findings in more detail, we acknowledge study limitations. 


\section{Limitations}

Although at an acceptable level for an exploratory study, the Cohen's kappa levels obtained for some of the variables were somewhat low, suggesting that agreement among coders might have been improved, whether through more training, a revised codebook, or both. Moreover, some of the variables may have been interpreted too broadly, clouding the results. For instance, "risk" included reference to risks posed by aquaculture to humans and ecosystems, as well as risks to aquaculture, such as weather conditions or water shortages. Collapsing these distinct aspects of risk in a single category may have obscured nuances in how aquaculture risk is reported; future research should disentangle these-and perhaps other-sub-themes. Attention to the sources quoted in a given article, such as whether they pertain to a government agency, private company, citizen, and so forth, would also provide insight into the framing of expertise about aquaculture-that is, whose voice is constructed as critical and "on the record" when it comes to discussing aquaculture risks and opportunities. Moreover, the coding scheme employed recognized the absence or presence of a theme, rather than its prominence (e.g., number of mentions per article), which may have modified the trends observed. Though selected to maximize diversity (e.g., in geographic region, U.S. population, and prominence/type of aquaculture), the four U.S. states (and their respective regional news publications) may have over-simplified complex differences. To this end, comparing news coverage from several states practicing the same type of aquaculture within a region (e.g., Louisiana, Mississippi, and Alabama, for catfish farming or Massachusetts, Maine, and Connecticut for oyster farming) would be instructive. Finally, although a limitation not unique to our study, we acknowledge that relying on online archives to access past news coverage conveys possible errors of omission; since we relied exclusively on online databases, it is possible that inaccuracies in indexing (on the part of the newspaper and/or the database), or the unavailability of certain content in digital form led to articles being unintentionally left out of the sample.

\section{Another "Risky" Technology}

Supporting past research (Schlag, 2010, 2011), for the majority of the study period, risk dominated the aquaculture discussion in both the regional and national newspapers sampled. Despite advances in sustainable aquaculture practices, diversification in species cultivated, as well as mounting evidence that aquaculture can reduce pressure on wild fisheries (Naylor et al., 2009), many articles examined tended to defer to well-worn territory in the aquaculture debate, mentioning risks such as the pollution released from crowded fish pens, unsustainable fish feed, and escapes of GM species. As exemplified in a 2011 Washington Post article:

[Aquaculture] has also raised serious environmental questions, ranging from whether raising carnivorous fish ends up depleting forage fish stocks to concerns about farmed fish escaping and mixing with wild species (Eilperin, 2011).
Given the agenda-setting function of the mass media, attention to risk across these varied media outlets, characterized by quotations such as the above, may further emphasize the prominence of risk as an important attribute of aquaculture, thus directing audience attention accordingly (Scheufele and Tewksbury, 2007).

Interestingly, two distinct spikes in media coverage of aquaculture in 2007 and 2010 align with similar upticks in coverage of risk, political/legal, economics, and science. A preliminary review of sampled articles from each year suggests several prominent stories that garnered international attention and, in some cases, controversy, including: the labeling of farm-raised catfish-like species imported from Vietnam, contaminated aquaculture products originating in China, and, more recently, regulation surrounding AquAdvantage, the first GM salmon to be raised in aquaculture operations. Arguably, each of these stories could be covered in terms of environmental or human health risk (e.g., illnesses related to contaminated seafood), political or legal issues (e.g., implications for foreign trade), economics (e.g., product sales), and science (e.g., genetic engineering). For example, highlighting both regulatory and human health issues, a 2007 New York Times article refers to U.S. FDA inspectors as "[tagging] 'filthy frozen scallops'; catfish, eel and shrimp laced with banned chemicals; unsafe additives; pesticides; and cancer-causing agents" (Barboza, 2007). For those without outside knowledge of aquaculture, this coverage may contribute to a "mediated reality" in which farmed seafood poses considerable risk-and thus, should be avoided (Binder et al., 2014). Focusing on environmental risk and the uncertain science of genetic engineering, a 2010 commentary in the Boston Globe condemning the FDA's proposed approval of AquAdvantage argues:

We need to rethink farmed fish, period. Aquaculture messes with Mother Nature far too much for the convenience of having fish available 24/7 ... Aquaculture represents the illusion of an infinite bounty, our denial that our resources are finite (Jackson, 2010).

Importantly, this quotation appears to posit that aquaculture is counterproductive to achieving sustainability, in that it does not promote sustainable use of a natural resource (see Kajikawa, 2008), but rather seeks to overcome the limitations of production by raising fish GM to grow efficiently in tightly controlled operations.

\section{Local and Sustainable}

News media coverage of aquaculture during the last 3 years has also included increasing attention to benefit and sustainability, a pattern that may be attributed, in part, to increasing attention to shellfish aquaculture in the Northeast (Maine and Massachusetts in our sample). Indeed, within the full sample, we see a significant association between the mention of benefit and shellfish aquaculture $\left[\chi^{2}(1)=6.51, p<0.05\right]$, but not between benefit and finfish aquaculture $\left[\chi^{2}(1)=1.70, p>0.05\right]$. Additionally, finfish aquaculture and sustainability are significantly associated within the full sample, with the majority of articles that mention finfish (62\%) not mentioning sustainability $\left[\chi^{2}(1)=17.90\right.$, $p<0.001]$. While some articles referred to seeding oysters as 
an environmental remediation strategy (e.g., in reef restoration projects in the Chesapeake Bay and New York Harbor), others described the "ecosystem services" such species contribute positively to the marine life surrounding them: "as filter feeders, they eat phytoplankton and remove nitrogen and phosphorous from the ecosystem, thereby improving the quality of water for the fish that swim in it" (Rudalevige, 2015).

Other articles linked benefit and sustainability within the context of the "local" food movement, such as quoting a state biologist claiming that Massachusetts oysters farmers produce a "healthy, sustainable, ecologically beneficial, and local food product” (Kandarian, 2015). Whereas finfish aquaculture carries an unsavory legacy of environmental impact and perceived risk, shellfish aquaculture-and oysters in particular-seems to conjure "foodie culture" and even haute cuisine; articles referenced sustainability in the same breath as "merroir": an oyster's unique flavor, developed from the waters in which it grows (Martell, 2011). This link between local foods and sustainability is often made with the understanding that local food production and distribution is more ecologically sound and socially equitable (Feenstra, 1997), which harkens back to the influence of the economic social system within sustainability.

The noted difference in coverage between aquaculture type (finfish or shellfish) also highlights the possibility that different fisheries lend themselves to different aquaculture practices, and with this, the opportunity to be more or less sustainable than their respective "wild harvest" counterparts. On the one hand, the distinct practices involved in shellfish aquaculture determined by the biology of the species, such as the ability to grow an organism without providing outside feed, may enable it to escape the environmentally unsustainable characterization historically attached to finfish aquaculture. On the other hand, from a social systems perspective, over the last 10 years, the political/legal and science systems, in the U.S. in particular, have sought to address various flaws in finfish aquaculture operations while encouraging more sustainable practices for emergent shellfish production. Importantly, given the more recent development of shellfish aquaculture in the U.S., it could be that insufficient time has passed to determine if shellfish aquaculture practices are, in fact, more sustainable than finfish aquaculture; emerging research, for instance, suggests that the waste products generated by oyster aquaculture operations may lead to considerable environmental impact on ecosystems (Lacoste and Gaertner-Mazouni, 2015). To this point, a longer term media analysis would be beneficial for examining how the public conversation about shellfish may change as scientific developments, regulatory decisions, and environmental impact studies emerge. Indeed, the prominence of these social systems in media coverage over time suggests what aspects of aquaculture audiences may find salient, and thus, indirectly, may influence opinion formation and support for practices and products (Scheufele, 1999; Nisbet, 2014).

\section{Regionality and Resonance}

Comparing within and between regional and national newspapers revealed differences in thematic prominence that suggest that the conversation about aquaculture, rather than being monolithic, may vary geographically within the U.S. Compared to the regional articles, a higher proportion of national newspaper articles covered risk, benefit, and sustainability issues. Drilling down further, considering coverage of risk, we find significant differences within both the national newspaper sample and the regional newspaper sample; in other words, the prominence afforded to the risks of aquaculture varies between regional and national news outlets, but also within each of these news types. These results are similar to those reported in Feldpausch-Parker et al. (2013), in that regional and national coverage of a technology or practice differs due to proximity and experience with the technology or similar technologies. In discussing aquaculture benefits, however, the four national newspapers were not significantly different, whereas the regional newspapers varied in their coverage; possibly, reporting on aquaculture benefits may be more closely tied to locale, such that the environmental benefits of growing oysters, for instance, is a relevant touchstone for readers of the Boston Globe, but less so for the Advocate's readership, as crawfish cultivation is not (at least historically) portrayed as a similarly "green" venture.

Likewise, coverage of sustainability—not significantly different among the national newspapers - varied within the regional publications. Coverage of risk, benefit, and sustainability thus appear "regionalized" and, perhaps, bounded to locally relevant aquaculture practices (Höijer et al., 2006). These results are reminiscent of Freeman et al. (2012), who compare public attitudes toward aquaculture in Germany and Israel and conclude that environmental concern has the opposite effect on support for aquaculture in each country depending on the context of concern; that is, concern for overtaxed fisheries prompts support for aquaculture among Germans, whereas concern about effluent pollution reduces support among Israelis. Coverage of political/legal and scientific issues, by contrast, was more consistent across and within-regional and -national articles. With the exception of political/legal coverage in the national sample (highest in the New York Times and lowest in USA Today), the prominence of politics and science appeared quite homogenous; future research could explore possible drivers of this effect, including discussion of certain landmark issues, such as the federal proposal to allow offshore aquaculture or the approval of AquAdvantage salmon.

Examining the co-occurrence of themes also suggests that discussion of aquaculture is often multi-faceted (Schlag, 2011), with multiple angles of the topic considered in a single article. When considering the full sample, and also within the national sample and regional sample, we found significant associations between the co-occurrence of (1) risk and political/legal; (2) risk and science; and (3) benefit and sustainability, which itself incorporates the systems of political/legal, science, and economics. Risk and benefit were significantly associated only in the regional sample, where just $13.7 \%$ of all articles mentioned both themes. These results follow patterns reported in past media analyses addressing the diffusion and adoption of new technologies, which find that media place heavier emphasis on either the benefits or the risks of an emerging technology or practice based on its (1) perceived risks to society and/or the environment; and (2) previous history and the community's experience with 
similar technologies (Friedman and Egolf, 2005; Batill and Feldpausch-Parker, 2013; Feldpausch-Parker et al., 2013). In the present study, the co-occurrence of risk or benefit with various social function systems (e.g., GM fish in the science system, localized business models for shellfish in the economics system, aquaculture foreign trade policies in the political/legal system) appears to follow these conditions, suggesting where a problem or advantage of aquaculture-perceived or otherwise, current or developing - may lie. By identifying the system or systems in which the problem(s) can be dealt and assuming that resonance (Luhmann, 1989) is taking place between the impacted systems, changes to a process-in this case, how aquaculture operations function-can then be made. Because news media articles often present multiple angles of an issue, such system perturbations are made visible for public critique. Thus, examining media coverage through the lens of social systems and sustainability provides a unique window into the emergence and diversification of aquaculture both nationally, and on a regional scale and-in the

\section{REFERENCES}

Ahrens, F. (2007). FDA Halts Imports of Some Chinese Seafood. Washington, DC: The Washington Post.

Amberg, S. M., and Hall, T. E. (2010). Precision and rhetoric in media reporting about contamination in farmed salmon. Sci. Commun. 32, 489-513. doi:10.1177/1075547009357599

Barboza, D. (2007). A Slippery, Writhing Trade Dispute. New York, NY: The New York Times.

Batill, K., and Feldpausch-Parker, A. M. (2013). "Hydrofracking in the news: how media coverage of hydraulic fracturing shapes public discourse about emerging energy technologies in the U.S.," in Proceedings of the 2013 Conference on Communication and Environment (Uppsala: International Environmental Communication Association), 176-190.

Beck, M. W., Brumbaugh, R. D., Airoldi, L., Carranza, A., Coen, L. D., Crawford, C., et al. (2011). Oyster reefs at risk and recommendations for conservation, restoration, and management. Bioscience 61, 107-116. doi:10.1525/bio.2011.61.2.5

Binder, A. R., Cacciatore, M. A., Scheufele, D. A., and Brossard, D. (2014). “The role of news media in the social amplification of risk," in The SAGE Handbook of Risk Communication, eds H. Cho, T. Reimer, and K. A. McComas (Los Angeles: SAGE), 69-85.

Boykoff, M. T., and Boykoff, J. M. (2004). Balance as bias: global warming and the US Prestige Press. Glob. Environ. Change 14, 125-136. doi:10.1016/ j.gloenvcha.2003.10.001

Bush, S. R., Belton, B., Hall, D., Vandergeest, P., Murray, F. J., Ponte, S., et al. (2013). Certify sustainable aquaculture? Science 341, 1067-1068. doi:10.1126/ science. 1237314

Carlucci, D., Nocella, G., De Devitiis, B., Viscecchia, R., Bimbo, F., and Nardone, G. (2015). Consumer purchasing behaviour towards fish and seafood products. Patterns and insights from a sample of international studies. Appetite 84, 212-227. doi:10.1016/j.appet.2014.10.008

Chapman, A. S., Stévant, P., and Larssen, W. E. (2015). Food or fad? Challenges and opportunities for including seaweeds in a Nordic diet. Botanica Marina 58, 1-11. doi:10.1515/bot-2015-0044

Chu, J., Anderson, J. L., Asche, F., and Tudur, L. (2010). Stakeholders' perceptions of aquaculture and implications for its future: a comparison of the U.S.A. and Norway. Marine Resour. Econ. 25, 61-76. doi:10.5950/0738-1360-25.1.61

Cohen, B. C. (1963). The Press and Foreign Policy. Princeton, NJ: Princeton University Press.

Corbett, J. B., and Durfee, J. L. (2004). Testing public (un)certainty of science: media representations of global warming. Sci. Commun. 26, 129-151. doi:10.1177/1075547004270234

D’Anna, L. M., and Murray, G. D. (2015). Perceptions of shellfish aquaculture in British Columbia and implications for well-being in marine social-ecological systems. Ecol. Soc. 20, 57. doi:10.5751/ES-07319-200157 absence of public opinion data-suggests conditions for social approval and disapproval.

\section{AUTHOR CONTRIBUTIONS}

LR designed the study, led efforts for data collection, analysis, and manuscript writing. AF-P assisted with study design and manuscript writing.

\section{ACKNOWLEDGMENTS}

The authors thank Margaret Bouchard and Brandon Sirois for their assistance with article coding.

\section{FUNDING}

This research was supported by National Science Foundation award \#1355457 to Maine EPSCoR at the University of Maine.

Diana, J. S. (2009). Aquaculture production and biodiversity conservation. Bioscience 59, 27-38. doi:10.1525/bio.2009.59.1.7

Duarte, C. M., Holmer, M., Olsen, Y., Soto, D., Marbà, N., Guiu, J., et al. (2009). Will the oceans help feed humanity? Bioscience 59, 967-976. doi:10.1525/ bio.2009.59.11.8

Eilperin, J. (2005). White House Seeks to Boost Fish Farms by Expanding into Open Waters. Washington, DC: The Washington Post.

Eilperin, J. (2011). White House Issues New Rules for Fish Farms in Federal Waters. Washington, DC: The Washington Post.

Fabiansson, C., and Fabiansson, S. (2016). Food and the Risk Society: The Power of Risk Perception. Burlington, VT: Ashgate.

Feenstra, G. W. (1997). Local food systems and sustainable communities. Am. J. Altern. Agric. 12, 28-36. doi:10.1017/S0889189300007165

Feldpausch-Parker, A. M., Burnham, M., Melnik, M., Callaghan, M. L., and Selfa, T. (2015). News media analysis of carbon capture and storage and biomass: perceptions and possibilities. Energies 8, 3058-3074. doi:10.3390/ en8043058

Feldpausch-Parker, A. M., Ragland, C. J., Melnick, L. L., Chaudhry, R., Hall, D. M., Peterson, T. R., et al. (2013). Spreading the news on carbon capture and storage: a state-level comparison of US media. Environ. Commun. 7, 336-354. doi:10.1 080/17524032.2013.807859

Feucht, Y., and Zander, K. (2015). Of earth ponds, flow-through and closed recirculation systems - german consumers' understanding of sustainable aquaculture and its communication. Aquaculture 438, 151-158. doi:10.1016/ j.aquaculture.2015.01.005

Freeman, S., Vigoda-Gadot, E., Sterr, H., Schultz, M., Korchenkov, I., Krost, P., et al. (2012). Public attitudes towards marine aquaculture: a comparative analysis of Germany and Israel. Environ. Sci. Policy 22, 60-72. doi:10.1016/ j.envsci.2012.05.004

Frewer, L., Miles, S., and Marsh, R. (2002). The media and genetically modified foods: evidence in support of social amplification of risk. Risk Anal. 22, 701-711. doi:10.1111/0272-4332.00062

Frewer, L. J., Bergmann, K., Brennan, M., Lion, R., Meertens, R., Rowe, G., et al. (2011). Consumer response to novel agri-food technologies: implications for predicting consumer acceptance of emerging food technologies. Food Sci. Technol. 22, 442-456. doi:10.1016/j.tifs.2011.05.005

Friedman, S. M., and Egolf, B. P. (2005). Nanotechnology: risks and the media. IEEE Technol. Soc. Mag. 24, 5-11. doi:10.1109/MTAS.2005.1563496

Gurău, C., and Ranchhod, A. (2016). The future of genetically-modified foods: global threat or panacea? Futures 83, 24-36. doi:10.1016/j.futures. 2016.06.007

Hall, T. E., and Amberg, S. M. (2013). Factors influencing consumption of farmed seafood products in the Pacific Northwest. Appetite 66, 1-9. doi:10.1016/ j.appet.2013.02.012

Hansen, A. (2010). Environment, Media, and Communication. New York: Routledge. 
Hites, R. A., Foran, J. A., Carpenter, D. O., Hamilton, M. C., Knuth, B. A., and Schwager, S. J. (2004). Global assessment of organic contaminants in farmed salmon. Science 303, 226-229. doi:10.1126/science.1091447

Höijer, B., Lidskog, R., and Thornberg, L. (2006). News media and food scares: the case of contaminated salmon. Environ. Sci. 3, 273-288. doi:10.1080/15693430601049645

Jackson, D. Z. (2010). Keep Frankenfish Fiction. Boston, MA: The Boston Globe.

Kajikawa, Y. (2008). Research core and framework of sustainability science. Sustain. Sci. 3, 215-239. doi:10.1007/s11625-008-0053-1

Kandarian, P. E. (2015). Their World: Oysters. Boston, MA: The Boston Globe.

Kaptan, G., Fischer, A. R. H., and Frewer, L. J. (2016). Extrapolating Understanding of Food Risk Perceptions to Emerging Food Safety Cases. Cambridge, MA: Harvard University Workshop.

Kasperson, R. E., and Kasperson, J. X. (1996). The social amplification and attenuation of risk. Ann. Am. Acad. Polit. Soc. Sci. 545, 95-105. doi:10.1177/00027 16296545001010

Kasperson, R. E., Renn, O., Slovic, P., Brown, H. S., Emel, J., Goble, R., et al. (1988). The social amplification of risk: a conceptual framework. Risk Anal. 8, 177-187. doi:10.1111/j.1539-6924.1988.tb01168.x

Komiyama, H., and Takeuchi, K. (2006). Sustainability science: building a new discipline. Sustain. Sci. 1, 1-6. doi:10.1007/s11625-006-0007-4

Lacoste, E., and Gaertner-Mazouni, N. (2015). Biofouling impact on production and ecosystem functioning: a review for bivalve aquaculture. Rev. Aquaculture 7, 187-196. doi:10.1111/raq.12063

Luhmann, N. (1989). Ecological Communication. Chicago: The University of Chicago Press.

Luoma, S. N., and Löfstedt, R. E. (2007). Contaminated salmon and the public's trust. Environ. Sci. Technol. 41, 1811-1814. doi:10.1021/es072497j

Martell, N. (2011). Merroir: Like 'Terroir' but More Watery. Washington, DC: The Washington Post.

Mazur, A. (1981). Media coverage and public opinion on scientific controversies. J. Commun. 31, 106-115. doi:10.1111/j.1460-2466.1981.tb01234.x

Mazur, N. A., and Curtis, A. L. (2006). Risk perceptions, aquaculture, and issues of trust: lessons from Australia. Soc. Nat. Resour. 19, 791-808. doi:10.1080/08941920600835551

McCombs, M. E., and Shaw, D. L. (1972). The agenda-setting function of mass media. Public Opin. Q. 36, 176-187. doi:10.1086/267990

Murray, G., and D'Anna, L. (2015). Seeing shellfish from the seashore: the importance of values and place in perceptions of aquaculture and marine social-ecological system interactions. Mar. Pol. 62, 125-133. doi:10.1016/ j.marpol.2015.09.005

National Oceanic and Atmospheric Administration (NOAA). (2016). Aquaculture in the United States. Available at: http://www.nmfs.noaa.gov/aquaculture/ aquaculture_in_us.html

Naylor, R. L., Hardy, R. W., Bureau, D. P., Chiu, A., Elliott, M., Farrell, A. P., et al. (2009). Feeding aquaculture in an era of finite resources. Proc. Natl. Acad. Sci. U.S.A. 106, 15103-15110. doi:10.1073/pnas.0905235106

Nisbet, M. C. (2014). "Framing, the media, and risk communication in policy debates," in The SAGE Handbook of Risk Communication, eds H. Cho, T. Reimer, and K. A. McComas (Los Angeles: SAGE), 216-227.

Nisbet, M. C., and Newman, T. P. (2015). "Framing, the media, and environmental communication," in The Routledge Handbook of Environment and Communication, eds A. Hansen, and R. Cox (New York: Routledge), 325-338.

Peterson, T. R., and Feldpausch, A. (2010). "Sustainability," in Encyclopedia of Science and Technology Communication, ed. S. H. Priest, Vol. 2 (Thousand Oaks, CA: SAGE), 861-865.

Pols, M. (2015). Why Seaweed is Maine's Crop to Watch. Portland, ME: Portland Press Herald.
Riffe, D., Lacy, S., and Fico, F. (2014). Analyzing Media Messages: Using Quantitative Content Analysis in Research, 3rd Edn. New York: Routledge.

Ross, L. G., Telfer, T. C., Falconer, L., Soto, D., and Aguilar-Manjarrez, J. (eds) (2013). "Site selection and carrying capacities for inland and coastal aquaculture," in FAO Fisheries and Aquaculture Proceedings (Rome: FAO), 21.

Rudalevige, C. B. (2015). Farms Satisfy Desires of Oyster Lovers and Help the Ocean, Too. Portland, ME: Portland Press Herald.

Scheufele, D. A. (1999). Framing as a theory of media effects. J. Commun. 49, 103-122. doi:10.1111/j.1460-2466.1999.tb02784.x

Scheufele, D. A., and Tewksbury, D. (2007). Framing, agenda setting, and priming: the evolution of three media effects models. J. Commun. 57, 9-20. doi:10.1111/j.1460-2466.2006.00326_1.x

Schlag, A. K. (2010). Aquaculture: an emerging issue for public concern. J. Risk Res. 13, 829-844. doi:10.1080/13669871003660742

Schlag, A. K. (2011). Aquaculture in Europe: media representations as a proxy for public opinion. Int. J. Fish. Aquaculture 3, 158-165.

Schlag, A. K., and Ystgaard, K. (2013). Europeans and aquaculture: perceived differences between wild and farmed fish. Br. Food J. 115, 209-222. doi:10.1108/00070701311302195

Senkowsky, S. (2004). Fear of fish: the contaminant controversy. Bioscience 54, 986-988. doi:10.1641/0006-3568(2004)054[0986:FOFTCC]2.0.CO;2

Slovic, P. (1987). Perception of risk. Science 236, 280-285. doi:10.1126/ science. 3563507

Sneddon, R. (2015). Kelp: It's What's for Dinner. Rockport, ME: Downeast Magazine.

Tarver, T. (2015). Sea-ing a better way to feed the world. Food Technol. 69, $23-29$.

Torrissen, O., Olsen, R. E., Toresen, R., Hemre, G. I., Tacon, A. G. J., Asche, F., et al. (2011). Atlantic salmon (Salmo salar): the 'super-chicken' of the sea? Rev. Fish. Sci. 19, 257-278. doi:10.1080/10641262.2011.597890

Valderrama, D., Hishamunda, N., and Zhou, X. (2005). Estimating Employment in World Aquaculture, Vol. 45. Phuket, Thailand: FAO Aquaculture Newsletter, $24-25$.

Valentinov, V. (2014). The complexity-sustainability trade-off in Niklas Luhmann's social systems theory. Syst. Res. Behav. Sci. 31, 14-22. doi:10.1002/ sres. 2146

Vanhonacker, F., Altintzoglou, T., Luten, J., and Verbeke, W. (2011). Does fish origin matter to european consumers? insights from a consumer survey in Belgium, NorwayandSpain. British FoodJ.113,535-549.doi:10.1108/00070701111124005

Waltz, E. (2016). GM salmon declared fit for dinner plates. Nat. Biotechnol. 34, 7-9. doi:10.1038/nbt0116-7a

Whitmarsh, D., and Palmieri, M. G. (2011). Consumer behaviour and environmental preferences: a case study of Scottish salmon aquaculture. Aquac. Res. 42, 142-147. doi:10.1111/j.1365-2109.2010.02672.x

World Commission on Environment and Development. (1987). Our Common Future. New York: Oxford University Press.

Conflict of Interest Statement: The authors declare that the research was conducted in the absence of any commercial or financial relationships that could be construed as a potential conflict of interest.

Copyright (c) 2016 Rickard and Feldpausch-Parker. This is an open-access article distributed under the terms of the Creative Commons Attribution License (CC BY). The use, distribution or reproduction in other forums is permitted, provided the original author(s) or licensor are credited and that the original publication in this journal is cited, in accordance with accepted academic practice. No use, distribution or reproduction is permitted which does not comply with these terms. 